\title{
Isolation sources of micro and macro elements among connection rice samples the creation of drought-resistant forms
}

\author{
Yu. K. Goncharova ${ }^{*}$, O.A. Bragina, E.M. Kharitonov, S.V. Goncharov, and N.A. Ochkas \\ ${ }^{1}$ FGBNU "Federal Rice Research Center ", Belozerny, 3, 350921 Krasnodar, RF \\ ${ }^{2}$ Kuban State Agrarian University, 350000 Krasnodar, RF \\ ${ }^{3} \mathrm{OOO}$ "Aratai", "Skolkovo", 143026 Moscow, RF
}

\begin{abstract}
Metals content affects not only for nutritional value of plants, but also their resistance to stress. So it was revealed that cationic composition changes hydration of cytoplasm. Hydration of cytoplasm positively correlated with content of alkali metals, a representative of which is potassium, and negatively with amount of alkaline earth metals (calcium, magnesium). Variability of rice collection samples in terms of content of potassium, sodium, calcium, magnesium, ammonium cations has been studied. Sources that are recommended to be used in breeding programs for the creation of drought-resistant forms are highlighted. The potassium content varied in the rice samples from 40 to $90 \%$. In 18 samples, its content did not exceed $70 \%$, in 13 it was above $80 \%$, which makes it possible to recommend them as sources of these trait: Olymp, Ivushka, Dozhdik, Berezka, Rapan, Aurora, Fisht. The study of the relationship between the content of cations showed their presence between the content of potassium and sodium - 0.87 , potassium and ammonium 0.45 , calcium and magnesium 0.35 .
\end{abstract}

\section{Introduction}

Rice is superior in nutritional value to most cereals [1-3]. Both animal and plant organisms need minerals to function. For humans, the most important of them are iron and zinc. Content of minerals in a plant is influenced by both genetic characteristics of sample and external factors, primarily soil on which it grows [4-6]. Rice can be a source of calcium, magnesium, phosphorus, selenium, zinc, manganese, iron, potassium. There is a wide variation in content of micro and macroelements both between subspecies and within a species [7-9].

Content of metals affects not only for nutritional value of plants, but also their resistance to stress. So it was revealed that the cationic composition changes hydration of the cytoplasm. Hydration cytoplasm positively correlated with the content of alkali metals, a representative of which is potassium, and negatively with the amount of alkaline earth metals (calcium, magnesium) [10-12].

\footnotetext{
${ }^{*}$ Corresponding author: yuliya_goncharova_20@mail.ru
} 
Colloidal protein particles carrying negative charge, like cations, are surrounded by a hydration shell. Charged particles with a higher mass $\mathrm{Mg} 2+, \mathrm{Ca} 2+$ are more strongly attracted to negatively charged protein molecules, neutralizing their charge, this causes decrease number of water molecules surrounding the protein. Monovalent charged particles have a weaker effect on hydration, increasing tissue hydration [13-15].

When analyzing breeding material, it should be borne in mind that the concentration of trace elements is up to 10 times higher in the embryo, bran, hulled rice than in polished white rice, which is usually eaten. So magnesium in bran was $(5.12 \%)$ and in polished rice $(0.51 \%)$ [16-18].

Adaptability to drought is also influenced by a number of other signs, the efficiency of mineral nutrition, photosynthesis, and tissue hydration. Samples with improved characteristics of drought resistance can be obtained by combining them in one sample [1921].

\section{Materials and methods}

Content of cations was determined in 50 varieties Russian breeding and collection samples of FRC. For measurements we used Kapel 105-M and Infralum devices. For the analysis, material was taken from 20 plants of each sample, in duplicate. Preparation of samples to obtain data on content of cations and anions included: selection of plant material (1 gram of sample), its homogenization, fixation with $10 \%$ alcohol, holding in a refrigerator for 1 day, centrifugation at 10-15 thousand rpm, selection of supernatant in pure $2 \mathrm{ml}$. test tube for analysis. The analysis on the Kapel 105-M device was carried out in accordance with the methods for the determination of trace elements. Statistica software was used for statistical processing of the data obtained.

\section{Results and Discussions}

Figure 1shows chromatogram obtained in MultiChrom program for Windows (C) 1993-2002 Ampersand Ltd for Flagman variety. Foregrams simultaneously show variability of samples in terms of the content of 5 cations: ammonium, potassium, calcium, sodium, magnesium. The amount of cations was expressed as a percentage per sample volume. Analysis of variance showed the reliability of difference between samples in composition of all studied cations Table 1.

Table 1. Analysis of variance reliability differences in composition of cations.

\begin{tabular}{|c|c|c|c|c|c|}
\hline \multicolumn{1}{|c|}{ Signs } & $\begin{array}{c}\text { Amount } \\
\text { squares }\end{array}$ & $\begin{array}{c}\text { Degrees } \\
\text { freedom }\end{array}$ & $\begin{array}{c}\text { Middle } \\
\text { square }\end{array}$ & $\mathrm{F}$ & $\mathrm{p}$ \\
\hline $\begin{array}{c}\text { Ammonium, } \\
\%\end{array}$ & 2771,49 & 47 & 58,9679 & 707,615 & 0,000 \\
\hline $\begin{array}{c}\text { Potassium, } \\
\%\end{array}$ & 14951,32 & 47 & 318,1132 & 3817,359 & 0,000 \\
\hline \begin{tabular}{c} 
Sodium, \% \\
\hline $\begin{array}{c}\text { Magnesium, } \\
\%\end{array}$
\end{tabular} & 11780,90 & 47 & 250,6574 & 3007,889 & 0,000 \\
\hline 985,44 & 47 & 20,9669 & 251,602 & 0,000 \\
\hline \begin{tabular}{c} 
Calcium, \% \\
\hline
\end{tabular} & 49,32 & 47 & 1,0494 & 12,593 & 0,000 \\
\hline
\end{tabular}




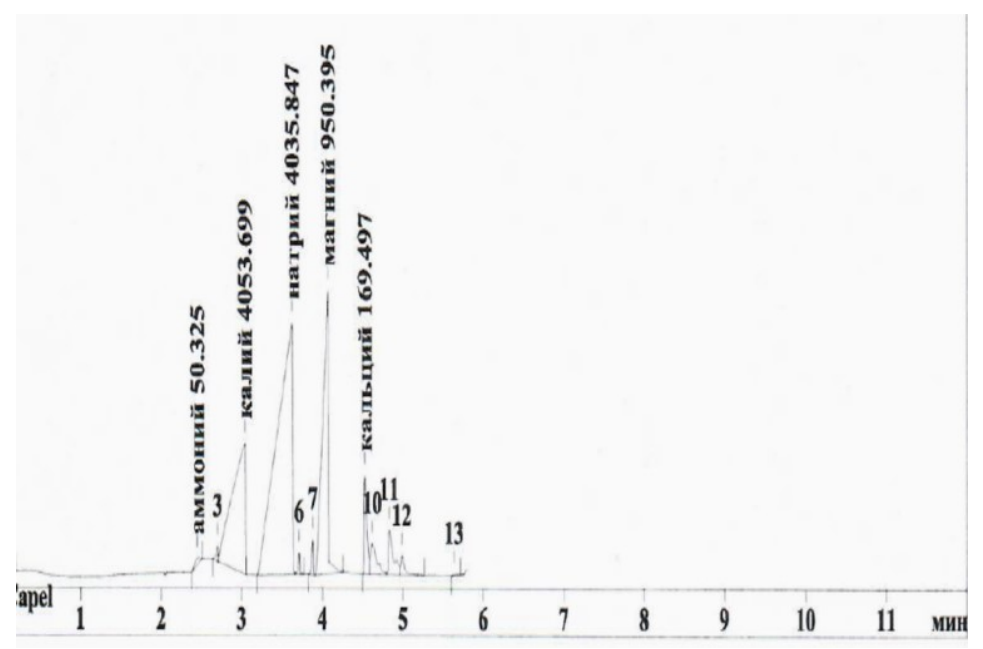

Fig. 1. Chromatogram obtained in MultiChrom program for Windows (C) 1993-2002 Ampersand Ltd. The number of cations in Flagman rice sample.

The presence of potassium activates many enzymes that regulate protein synthesis. The effect of potassium on respiration and photosynthesis and movement of its products in plants has been established. The increased content of potassium activates the work of stomata, increases turgor. In our studies, the potassium content varied in rice samples from 40 to $90 \%$. In 18 samples, its content did not exceed $70 \%$, in 13 it was above 80 , but less than $90 \%$, which makes it possible to recommend them as sources according to the characteristic, these are varieties: Olymp, Ivushka, Dozhdik, Berezka, Rapan, Aurora, Fisht (figure 2).

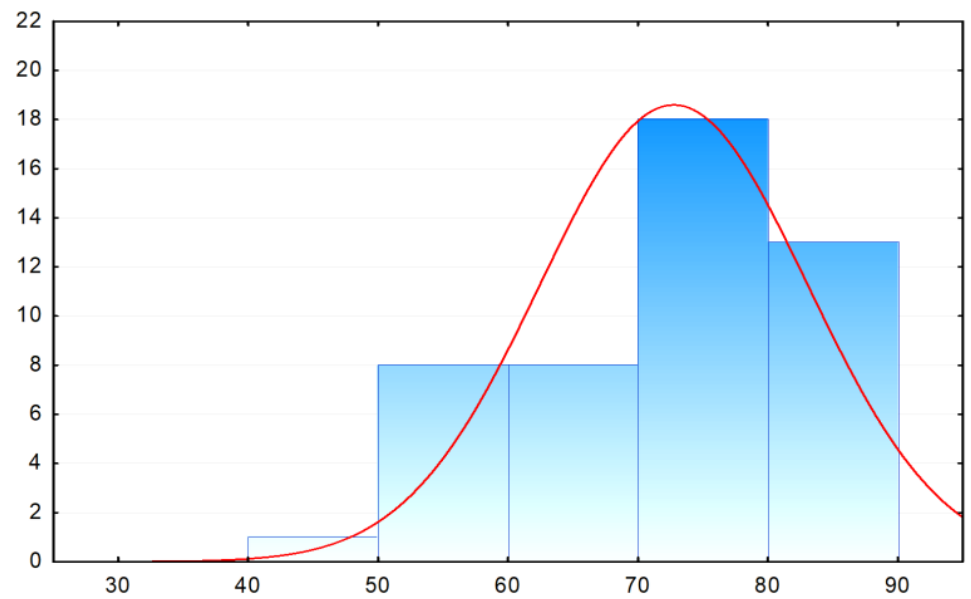

Fig. 2. Distribution samples by groups according to content of potassium cations. Red line is expected normal distribution.

$\mathrm{Y}$-axis is number of samples. $\mathrm{X}$-axis - feature value.

Sodium ions can be toxic. However, some salt tolerant plants (halophytes) contain high concentrations of sodium. Examples of such species: salineros, sea vault, sarsazan, some types of tamarix. Solyanka plants contain up to $6 \%$ salts in the cell sap, which reduces 
water potential, and ensures flow of water even during salinity and drought. It is possible to avoid the toxicity of salts due to their compartmentalization in vacuoles, which reduces their damage to enzymatic complex of cytoplasm. Sodium content varied in rice samples from 5 - 44\%. In 38 samples, its content did not exceed $25 \%$, in 7 samples it was higher than 25 , but less than $45 \%$, which allows us to recommend them as sources for this trait: Flagman, Courage, Smuglyanka, Don Nong, Mars (Figure 3).

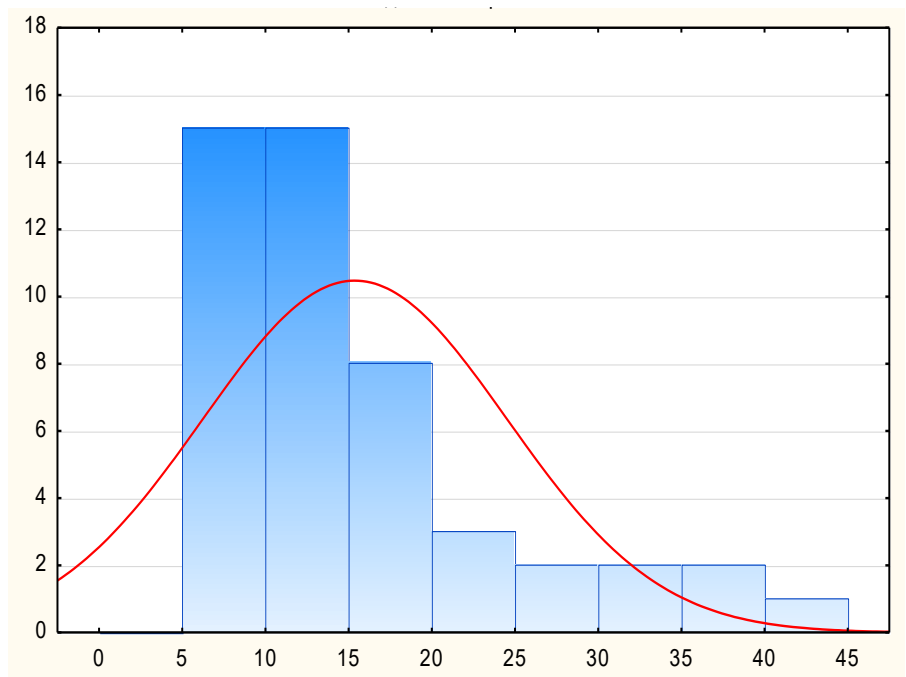

Fig. 3. Distribution samples into groups according to content of sodium cations. Red line is expected normal distribution.

$\mathrm{Y}$-axis is number of samples. $\mathrm{X}$-axis - feature value.

$\mathrm{Ca} 2+/ \mathrm{Mg} 2+$ ratio is of great importance for the life of plants and regulates many metabolic processes. Magnesium content varied in the rice samples from $2-14 \%$ (Figure 4).

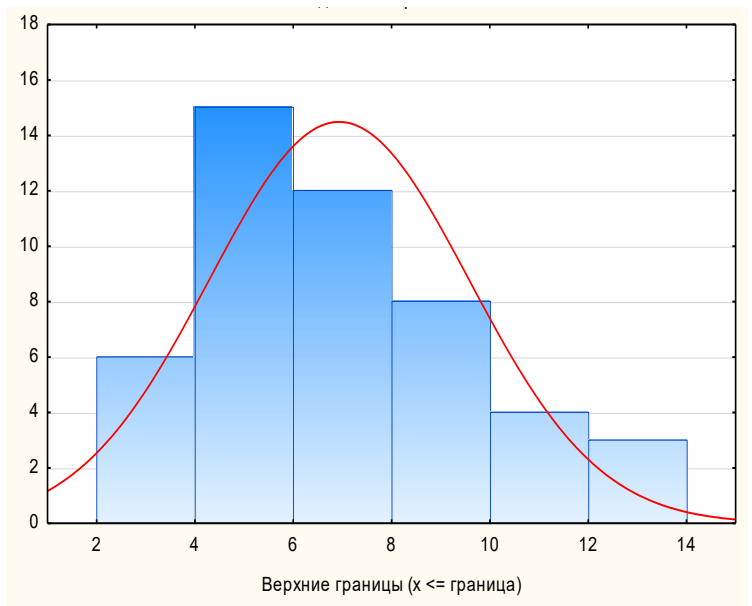

Fig. 4. Distribution samples by groups according to magnesium cations content. Red line is expected normal distribution.

$\mathrm{Y}$-axis is number of samples. $\mathrm{X}$-axis - feature value. 
In 40 samples, its content did not exceed $10 \%$, in 10 samples it was above $10 \%$, but less than $14 \%$, which makes it possible to recommend them as sources on this trait: Natasha, Orion, Partner, Gamma.

Calcium is also very important for the body, as it stabilizes the cell membranes, with a lack of it, the root system suffers especially. The calcium content varied in the rice samples from $0.07-2.33 \%$. In 36 samples, its content did not exceed $1 \%$, in 7 samples it was higher than $1.5 \%$, which makes it possible to recommend them as sources according to the characteristic, these are varieties: Polevik, Krepysh, Ivushka, Flagman, Courage. The range of variation for studied traits is presented in Table 2.

Table 2. The range variation in cations content in rice samples.

\begin{tabular}{|r|c|c|c|c|c|c|}
\hline Cation content & N obs. & Average & Minimum & Maxim. & St. Dev. & $\begin{array}{c}\text { Std. - } \\
\text { errors }\end{array}$ \\
\hline \hline Ammonium, \% & 48 & 4,16 & 0,050 & 18,75 & 4,43 & 0,63 \\
\hline \hline Potassium, \% & 48 & 72,76 & 43,78 & 86,19 & 10,29 & 1,48 \\
\hline \hline Sodium, \% & 48 & 15,38 & 5,30 & 43,58 & 9,14 & 1,32 \\
\hline Magnesium, \% & 48 & 6,93 & 3,35 & 13,86 & 2,64 & 0,38 \\
\hline Calcium, \% & 48 & 0,76 & 0,07 & 2,33 & 0,59 & 0,085 \\
\hline
\end{tabular}

Conducted study of correlations between content of cations showed their presence of strong and moderate negative correlations between the content of potassium and sodium 0.87 , potassium and ammonium -0.45 , and weak positive correlations between calcium content and magnesium 0.35 table 3 .

Table 3. Correlation relationships between content of cations in rice samples.

\begin{tabular}{|c|c|c|c|c|c|c|}
\hline Trait & $\begin{array}{c}\text { Aver } \\
\text { age }\end{array}$ & $\begin{array}{c}\text { Magnesiu } \\
\mathrm{m}, \%\end{array}$ & $\begin{array}{c}\text { Ammon } \\
\text { ium, \% }\end{array}$ & $\begin{array}{c}\text { Potassiu } \\
\mathrm{m}, \%\end{array}$ & $\begin{array}{c}\text { Sodium, } \\
\%\end{array}$ & $\begin{array}{c}\text { Calcium } \\
\%\end{array}$ \\
\hline Ammonium, \% & 4,33 & $-0,08$ & 1,00 & $-0,45$ & 0,06 & $-0,11$ \\
\hline Potassium, \% & 72,93 & $-0,06$ & $-0,45$ & 1,00 & $-0,87$ & $-0,22$ \\
\hline Sodium, \% & 15,55 & $-0,20$ & 0,06 & $-0,87$ & 1,00 & 0,18 \\
\hline Magnesium, \% & 7,10 & 1,00 & $-0,08$ & $-0,06$ & $-0,20$ & 0,35 \\
\hline Calcium, \% & 0,93 & 0,35 & $-0,11$ & $-0,22$ & 0,18 & 1,00 \\
\hline
\end{tabular}

\section{Conclusions}

Variability collection rice samples in terms of potassium content, sodium, calcium, magnesium, ammonium cations was studied. Sources that are recommended to be used in breeding programs to create drought-resistant forms were identified.

Potassium content varied in rice samples from 40 to $90 \%$. In 18 samples, its content did not exceed $70 \%$, in 13 it was above $80 \%$, which makes it possible to recommend them as sources of trait: Olympus, Ivushka, Dozhdik, Berezka, Rapan, Aurora, Fisht.

Magnesium content in the rice samples varied from 2 to $14 \%$. In 40 samples it did not exceed 10\%. Sources of trait are variety: Natasha, Orion, Partner, Gamma.

Calcium content varied in the rice samples from $0.07-2.33 \%$. In 36 samples, its content did not exceed 1\%, sources are varietyes: Polevik, Krepysh, Ivushka, Flagman, Courage.

Study relationship between content of cations showed their presence between content of potassium and sodium -0.87 , potassium and ammonium -0.45 , calcium and magnesium 0.35 . 
This work was carried out with the financial support of the Russian Science Foundation No. 1916-00064.

\section{References}

1. U. M. Lanfer-Marquez, J. Food Comp Anal, 18, 4 (2005)

2. M. S. Akter, M. Ahmed, Afr. J. Food Sci, 7, 8 (2013)

3. B. H. Jenning, C.A. Akoh, J. Food Chem, 114, 4 (2009)

4. P. Bhattacharjee, R. S. Singhal, P. R. Kulkarni, Inter. J. Food Sci Technol, 37, 1 (2013)

5. R Bisne, A K. Sarawgi, J. Agric. Res., 33, 3 (2008)

6. I. Buresova, I. Sedlackova, O. Famera, J. Lipavsky, 56 (2010)

7. C. Diako, E. Sakyi-Dawson, B. Bediako-Amoa, F. K. Saalia, Ann. Food Sci. Technol., 12, 1 (2011)

8. O. A. T. Ebuehi, A. C. Oyewole, Afr. J. Biote. Chu., 6, 8 (2008)

9. S. L. Jiang, J. G. Wu, Y. Feng, X. E. Yang, C. H. Shi, J. Agric. Food Chem., 55 (2007)

10. V. C. Mbatchou, S. Dawda, Int. J. Res. Chem. Environ., 3,1 (2013)

11. A. O. Oko, S. C. Onyekwere, Int. J. Biotechnol. Biochem., 6, 6 (2010)

12. A. O. Oko, S. I. Ugwu, Afr. J. Biotechnol., 6, 8 (2011)

13. A. O. Oko, B. E. Ubi, A. A. Efisue, N. Dambaba, Int. J. Agric. Forest., 2, 2 (2012)

14. R. Sompong, S. Siebenhandl-Ehn, G. Linsberger-Martin, E. Berghofer, Food Chem., 124, 1 (2011)

15. D. K. Verma, M. Mohan, P. K. Prabhakar, P. P. Srivastav, J. Int. Food Res. J., 22, 4 (2015)

16. A. Vlachos, I. S. Arvanitoyannis, Critical Reviews Food Sci. Nutr., 48 (2008)

17. K. M. Wang, J. G. Wu, G. Li, D. P. Zhang, Z. W. Yang, C.H. Shi, J. Cereal Sci., 54, 1 (2011)

18. D. K. Verma, P.P. Srivastav, J. Science Direct Rice Science, 24, 1 (2017)

19. F. M. Anjum, I. Pasha, M. A. Bugti, M.S. Butt, J. Agri. Sci, 44, 2 (2007)

20. J. K. Goncharova, S. V. Gontcharov, E. E. Chicharova, Russian J. of Genetics, 54, 7 (2 018)

21. E. M. Kharitonov, Y. K. Goncharova, E. A. Maliuchenko, Russian J. of Genetics: Applied Research, 7, 6 (2017)

22. J. K. Goncharova, E. M. Kharitonov, Russian J. of Genetics: Applied Research, 6, 3 (2016) 